Original Research Article

\title{
Effect of Moringa oleifera aqueous leaf extract on hepato-renal changes of albino rats induced with Salmonella typhimurium
}

\author{
Nasiru Suleiman ${ }^{1}$, Bulama Ibrahim ${ }^{2}$, Bagudo Ibrahim Ahmed ${ }^{3}$, Attahiru Zayyanu ${ }^{4}$
}

\begin{abstract}
${ }^{1}$ Department of Veterinary
Physiology and Biochemistry,

Faculty of Veterinary Medicine,

Usman Danfodio University,

Sokoto, Nigeria

${ }^{2}$ Department of Microbiology,

Kebbi State University of

Science and Technology, Aliero

Kebbi State, Nigeria

${ }^{3}$ Department of Veterinary

Physiology and Biochemistry,

Faculty of Veterinary Medicine,

University of Maiduguri,

Nigeria

${ }^{4}$ Department of Veterinary services, Sokoto State Ministry

Agriculture, Sokoto, Nigeria
\end{abstract}

Received: 30 October 2016

Accepted: 29 November 2016

*Correspondence to:

Dr. Bulama Ibrahim,

Email: chiroothman@gmail.com

Copyright: (c) the author(s), publisher and licensee Medip Academy. This is an openaccess article distributed under the terms of the Creative Commons Attribution NonCommercial License, which permits unrestricted noncommercial use, distribution, and reproduction in any medium, provided the original work is properly cited.

\begin{abstract}
Background: This study was designed to evaluate the effect of Moringa oleifera against Salmonella typhimurium infected changes in liver and kidney function parameters in albino rats.

Methods: Twenty acclimatized albino rats were divided into four groups of five rats each (groups A-D). Groups B, C and D were exposed to $0.1 \mathrm{ml}\left(3.0 \times 10^{4}\right.$ CFU) of Salmonella typhimurium. Six hours post- infection, Groups B and C were treated with 50 and $100 \mathrm{mg} / \mathrm{kg}$ of Moringa oleifera aqueous leaf extract respectively and continued for 21 days. Group D was not treated while group A was neither infected nor treated. Serum alkaline phosphatase (ALP), alanine transaminase (ALT), aspartate transaminase (AST), bilirubin, albumin, total protein, urea and creatinine were estimated using standard methods. All data were collected and analyzed in October 2015.

Results: S. typhimurium infection significantly $(\mathrm{p}<0.05)$ increased the levels of ALP, ALT, AST, bilirubin, urea and creatinine when compared with control levels (Group A). Total protein and albumin concentrations were significantly $(\mathrm{p}<0.05)$ reduced following the infection. However, Moringa oleifera supplementation was associated with significant $(\mathrm{p}<0.05)$ decrease in the levels of ALP, ALT, AST, bilirubin, urea and creatinine. It is also associated with decrease in concentrations of total protein and albumin.

Conclusions: This study showed S. typhimurium infection induced changes in liver and kidney function parameters and also revealed possible amelioratory effects to these changes after Moringa oleifera supplementation.
\end{abstract}

Keywords: Moringa oleifera, Albino rat, Salmonella typhimurium

\section{INTRODUCTION}

Moringa oleifera Lam (Moringaceae) is a plant with vast value found in many countries of the tropics and subtropics. Various parts of this plant comprise valuable minerals, and can be a good source of protein, vitamins, $\beta$ -carotene and many phenolics. ${ }^{1}$ The Moringa plant furnishes a good and exceptional combination of zeatin, quercetin, $\beta$ - sitosterol, caffeoylquinic acid and kaempferol. $^{2}$ Besides its high nutritional value, $M$. oleifera is very important for its remarkable collection of medicinal uses and being utilized for the treatment of 
different ailments in the indigenous systems of medicine. ${ }^{3}$ Many parts of this plant such as the leaves, roots, seed, bark, fruit, flowers and immature pods act as cardiac and circulatory stimulants, possess antitumor, antipyretic, antiepileptic, anti-inflammatory, antiulcer, antispasmodic, diuretic, antihypertensive, cholesterol lowering, antioxidant and anti-diabetic activities. ${ }^{4}$ Various studies showing the amelioratory effect of moringa on liver and kidney injuries caused by chemicals and drugs have been reported, ${ }^{5}$ but there is little information on its effect on hepatorenal injury induce by microorganisms that affect these organs such as Salmonella.

Salmonella infections are one of the widespread diseases with public health importance. The disease drain cause by Salmonellosis is more than that cause by any other foodborne pathogen. The global approximated cases of gastroenteritis caused by Salmonella species puts up to 9.3 million each year. ${ }^{6}$ Antibiotic resistance and multiresistance of Salmonella spp. have increased substantially, particularly in developing countries where the use of antibiotics in the treatment of humans and animals is indiscriminately high. Various Salmonella serovars resistant to conventional antibiotics such as ampicillin, chloramphenicol, trimethoprimsulfamethoxazole, and other newer antibiotics (quinolones and extended-spectrum cephalosporins) have been reported with increasing frequency in many areas of the world. ${ }^{7}$ Among the nonty phoidal Salmonella enterica serovar typhimurium has been reported to show multidrug resistance. ${ }^{8}$

This increasing prevalence of multi-drug resistant strains of bacteria necessitates the search for new infectionfighting strategies.

Liver disturbances such as hepatomegaly, toxic hepatitis and jaundice were reported in patient with salmonellosis. ${ }^{9}$ Two pathogenic mechanisms are likely to be involved in liver damage in salmonellosis- Salmonella bacteria and the endotoxin released in the process of bacteriolysis. It is well known that salmonella bacteria tend to damage the hepatobilliary system and hepatic Kupffer cells are targets for the salmonella endotoxin. Acute kidney injury is also one of the complications of salmonellosis. ${ }^{10}$ The aim of this work is to assess the effect of Moringa oleifera aqueous leaf extracts on liver and kidney injuries in albino rats experimentally infected with Salmonella typhimurium.

\section{METHODS}

\section{Collection of plant materials}

Fresh leaves of mature Moringa oleifera were collected from KSUSTA Botanical garden. The plant was identified at the Department of Biological Sciences Kebbi State University of Science and Technology Aliero with Voucher number L.75, the plant was then brought to the
Microbiology Laboratory in a sterile polythene bag for analysis.

\section{Preparation of plant extract}

The leaves were gently cleaned and washed under running tap water to remove dirt after which they were air-dried at room temperature for two weeks. They were ground into powdered form using clean laboratory motor and pestle and then stored in a sterile plastic container. $50 \mathrm{~g}$ of the powder (Moringa oleifera Leaves) was soaked in $250 \mathrm{ml}$ of water in a conical flask for two weeks with regular shaking at room temperature. This was then filtered and the solvent evaporated using Rotary Evaporator and kept at $4^{\circ} \mathrm{C}$ before used. ${ }^{11}$

\section{Experimental animals}

Albino rats used in this study were obtained from animal house of the Department of Veterinary Physiology and Biochemistry, Usmanu Danfodiyo University Sokoto, Nigeria and weighed between 200 to $250 \mathrm{~g}$. They were tested to ensure that they were negative for Salmonella typhimurium before inoculation. Vital grower feed and cleaned water were provided ad-libitum.

\section{Test organism}

Salmonella typhimurium was sourced from National Veterinary Research Institute Vom, Plateu State, Nigeria. The organism was subcultured on Salmonella-Shigella agar to confirm the viability and then preserved in the refrigerator at $4^{\circ} \mathrm{C}$.

\section{Study design}

The infective dose was prepared as described by. ${ }^{12} \mathrm{~A}$ loopful of the organism stored in nutrient agar slant was transferred into test tube containing $10 \mathrm{ml}$ sterilized peptone water and incubated at $37^{\circ} \mathrm{C}$ for $18-24 \mathrm{hrs}$. Rats were divided into 4 groups of 5 rats $(n=5)$ each.

Table1: Group and treatment of experimental rats.

\begin{tabular}{|ll|}
\hline Group & Treatment \\
\hline A & Non infected non treated. \\
\hline B & $\begin{array}{l}\text { Infected with Salmonella typhimurium } \text { and } \\
\text { treated with } 0.5 \mathrm{ml} \text { of Moringa oleifera } \\
\text { aqueous leave extract. }\end{array}$ \\
\hline C & $\begin{array}{l}\text { Infected with Salmonella typhimurium and } \\
\text { treated with } 1 \mathrm{ml} \text { of Moringa oleifera } \\
\text { aqueous leave extract. }\end{array}$ \\
\hline D & $\begin{array}{l}\text { Infected with Salmonella typhimurium but } \\
\text { not treated. }\end{array}$ \\
\hline
\end{tabular}

Group A were not infected and were used as control, group $\mathrm{B}$, group $\mathrm{C}$ and group $\mathrm{D}$ rats were orally challenged with $0.1 \mathrm{ml}\left(3.0 \times 10^{4} \mathrm{CFU}\right)$ of Salmonella typhimurium. Group B and Group C were administered 
with $50 \mathrm{mg}$ and $100 \mathrm{mg}$ respectively of the plant extract after six (6) hours of infection. Group D was not treated with the plant extract. Groups and their treatments are shown in Table 1.

\section{Biochemical analysis}

Serum alanine aminotransferase and aspartate aminotransferase were determined by the method reported ealier. ${ }^{13}$ Assay of serum alkaline phosphatase, bilirubin, albumin, total protein, Urea and creatinine were carried out according to standard methods. ${ }^{14-18}$

\section{Statistical analysis}

Result were expressed and presented as means \pm SD. Data were analyzed by one way analysis of variance (ANOVA). Duncans New Multiple Range Test was used for multiple comparisons. Statistical Package for Social Science (SPSS) Version 22 was used for the analyses. All data were collected and analyzed in October 2015.

\section{RESULTS}

The results of serum AST, ALT, bilirubin, total protein and albumin of all the groups are shown in Figure 1.

The results indicated significant increase $(p<0.05)$ in AST, ALT and bilirubin levels in group D compared to group A showing effect of $S$. typhimurium infection on these parameters. These levels were significantly $(\mathrm{p}<0.05)$ decreased in groups B and C treated with $1 \mathrm{ml}$ and $0.5 \mathrm{ml}$ of the extract respectively. Total protein and albumin levels were decreased significantly $(p<0.05)$ in group D and increased significantly $(\mathrm{p}<0.05)$ in groups $B$ and $\mathrm{C}$.

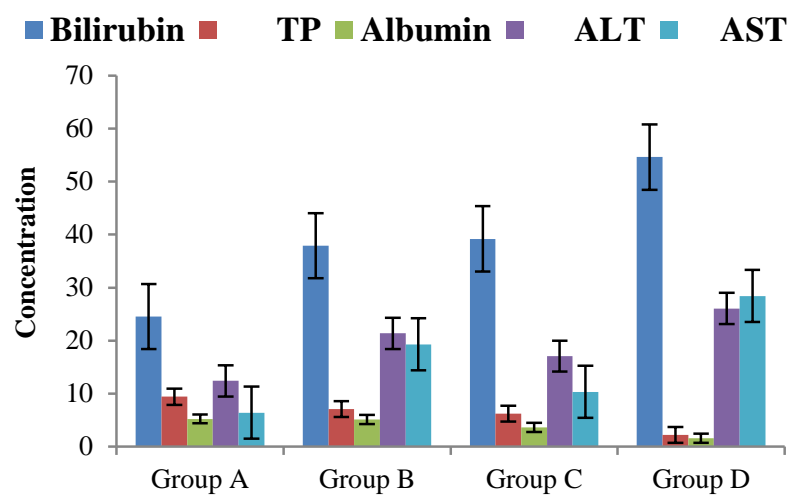

TP- Total Protein, ALT- Alanine Aminotransferase, ASTAspartate Aminotransferase, Group A- non infected non treated, Group B- infected and treated with $50 \mathrm{mg} / \mathrm{kg}$ of Moringa oleifera leaf extracts, Group C- infected and treated with $100 \mathrm{mg} / \mathrm{kg}$ of Moringa oleifera leaf extracts, Group D- infected but not treated

Figure 1: The effects of $S$. typhimurium infection and aqueous leaf extract of Moringa oleifera on liver function parameters key.
Figure 2 represents the effects of $S$. typhimurium infection and plant extract on some of the kidney function parameters. The results showed that group D rats have significant increase in the concentrations of creatinine, ALP and urea compared to group A while groups B and $C$ rats have significant decrease in the levels of these parameters compairing with group D.

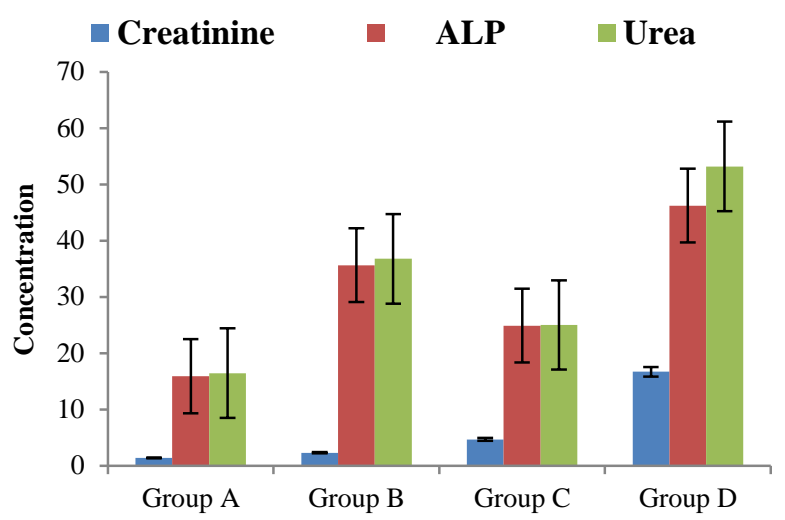

ALP- Alkaline Phosphatase, Group A- non infected non treated, Group B- infected and treated with $50 \mathrm{mg} / \mathrm{kg}$ of Moringa oleifera leaf extracts, Group C- infected and treated with $100 \mathrm{mg} / \mathrm{kg}$ of Moringa oleifera leaf extracts, Group D- infected but not treated.

Figure 2: The effects of $S$. typhimurium infection and aqueous leaf extract of Moringa oleifera on kidney function parameters key.

\section{DISCUSSION}

Salmonella typhimurium infection has been known to cause liver and kidney injury by tissue invasion of the bacteria, release of endotoxin, dehydration and hypoxia. The result of this study showing significant raise in the levels of AST, ALT, ALP, urea and bilirubin in the non treated group is a pointer to this. Significant decrease in total protein, albumin and increase in creatinine concentrations is an indication of functional impairment of the two organs. This trend was reversed in the groups treated with aqueous leave extracts of Moringa oleifera. This indicates that the plant extracts could have curative effect against the injury inflicted by the bacteria.

ALT and AST are cytosolic enzymes use to assess hepatocellular injury due to their increase release in to the circulation following damage to the hepatocytes. The significant drop in the levels of these enzymes due to Moringa oleifera treatment can be attributed to the antiinflammatory properties of the plant. The antiinflammatory activity can be traced to flavonoids like quecetin and phenolic acid present abundantly in the leaves of MO. ${ }^{19}$ These compounds have documented antiinflammatory properties. ${ }^{10}$ Salmonellosis is associated with inflammation and ulceration of the gut and liver of which oxidative lipid modification plays an important role in exacerbating the disease. Therefore the observed 
hepatocurative effect could also be associated with the antioxidant activity of Moringa oleifera as reported by. ${ }^{5}$

The result of serum total bilirubin revealed significant difference in group $\mathrm{D}$ when compared with group $\mathrm{A}$, which can be as a result of hemolysis and liver damage. Therefore, the significant $(\mathrm{P}<0.05)$ decrease in the level of bilirubin in Moringa oleifera extract treated groups suggests the potency of the extract to alleviate or protect damage to red blood cell membrane. Jaundice in patient with salmonellosis had been reported earlier. ${ }^{20}$

Our result indicated a significant increase in total protein and albumin concentrations in treated groups (groups B and C) when compared with the control group (group D). Protein and albumin are synthesized by the liver; hence their level in the blood is an index of liver function. Thus, total protein and albumin levels which were significantly $(\mathrm{P}<0.05)$ reduce by $S$. typhimurium infection but significantly $(\mathrm{P}<0.05)$ increase by treatment with leaves extracts of Moringa oleifera strongly suggests that the plant extracts ameliorated the liver damage induced by the bacterial infection. Similar findings were observed in patients diagnosed with salmonellosis. ${ }^{21,22}$

The findings in this study revealed significantly $(\mathrm{P}<0.05)$ higher levels of urea and creatinine in group D compared to group A. Blood urea, which is derived from normal metabolism of protein and excreted in the urine is usually elevated in blood when there is glomerular damage. Similarly, creatinine, a metabolite of creatine, which under normal condition is excreted completely in the urine via glomerular filtration, accumulates in the blood when there is impaired kidney function. ${ }^{22}$ There is a unique relationship between $S$ typhimurium and macrophages in the liver, spleen, intestinal lymphoid follicles, and mesenteric lymph nodes which could be responsible for the pathogenesis. Functionally active cytokines (TNF alpha, IL-1, interferon alpha and beta) are synthesized by macrophage cells and are an important source of arachidonate metabolites and reactive oxygen intermediates. These products can lead to cellular necrosis, other inflammatory cells recruitment, immune system stimulation and vascular instability. ${ }^{23}$ Consequently, the Moringa oleifera extract-treated groups showed significantly $(\mathrm{P}<0.05) \quad$ lower concentration of creatinine and urea suggesting the potency of the plant in protecting the kidney against or restoring it from $\mathrm{S}$ typhimurium induced damage. This could be due to the anti-inflammatory and antioxidant activities of the Moringa oleifera leaves which had been shown to be attributable to the presence of polyphenols and tannins. ${ }^{10}$ Increased levels of urea and creatinine observed in this work have also been reported in patients with salmonellosis. ${ }^{22}$

\section{CONCLUSION}

This study showed S. typhimurium induced changes in some liver and kidney function parameters and also revealed possible amelioratory effects to these changes after Moringa oleifera supplementation.

Moringa oleifera is an interesting plant for its contribution in bioactive compounds. The high contribution in bioactive compounds may explain the pharmacological properties ascribed to Moringa oleifera leaves.

\section{ACKNOWLEDGMENTS}

The authors hereby acknowledged the contributions of Mal. Ngaski and Rilwanu Muhammed.

Funding: No funding sources

Conflict of interest: None declared

Ethical approval: The study was approved by the Institutional Ethics Committee

\section{REFERENCES}

1. Abdull-Razis AF, Ibrahim MD, Kntayya SB. Health Benefit of Moringa oleifera. Asian Pacific J. of Canc. Prev. 2014;(20):8571-6.

2. Leone A, Spada A, Battezzati A, Schiraldi A, Aristil J, Bertoli S. Cultivation, Genetic, Ethnopharmacology, Phytochemistry and Pharmacology of Moringa oleifera Leaves: An Overview. Int. J. Mol. Sci. 2015;16:12791-835.

3. Anwar F, Latif S, Ashraf M, Gilani AH, Oleifera M. A Food Plant with Multiple Medicinal Uses. Phytother. Res. 2007;21:17-25.

4. Paliwal R, Sharma V. A review on horse radish tree (Moringa oleifera): A multipurpose tree with high economic and commercial importance. Asian J. Biotechnol. 2011;3:317-28.

5. Saalu LC, Ogunlade B, Ajayi GO, Oyewopo AO, Akunna GG, Ogunmodede OS. The hepatoprotective potentials of Moringa oleifera leaf extract on alcohol-induced hepato- toxicity in wistar rat. Am. J. Biotechnol. Mol. Sci. 2012;21:6-14

6. Eng S, Pusparajaha P, Ab- Mutalib N, Sera H, Chand K, Leea L. Salmonella: A review on pathogenesis, epidemiology and antibiotic resistance. Frontiers in Life Sci. 2015.

7. Mijovic G, Andric B, Terzic D, Lopicic M, Dupanovic. B. Antibiotic Susceptibility of Salmonella Spp; A Comparison of Two Surveys With A 5 years Interval. JIMAB. 2012;37:193.

8. Dhanashree B. Antibiotic susceptibility profile of Salmonella enterica serovars: Trend over three years showing reemergence of chloramphenicol sensitivity and rare serovars. Indian J. Med. Sci. 2007;61(10):576-9.

9. Stoycheva M. Liver Disturbances in Patients with Salmonellosis. Trakia J. of Sci. 2006;4(2):23-7.

10. León LPS, Otero WMD, Gómez. MD. Fever, Jaundice and Hepatitis: It is not always a Viral Infection. Rev. Col. Gastroenterol. 2015;30(3):287-91. 
11. Sofowara A. Medicinal Plants and Traditional Medicine in Africa Spectrum Books Ltd, Ibadan; 2003:289.

12. Rofaiil SK, Soliman R, Abo-Elmenemand OF, Mahmoud MH. Studies on Some Medicinal Plant Extracts as Immunostimulant in rats Experimentally infected With Salmonella typhimurium. Egypt. J. Agric. Res. 2011;89(1).

13. Reitman S, Frankel S, Colourimetric method for the determination of serum transaminases. Am. J. Clin. Pathol. 1957;28:56-61.

14. Rec GS. Calometric method of serum alkaline phosphatase determination. J. Clin. Biochem. 1972;10:182.

15. Jendrassic L, Grof P. Calomertic method for serum bilirubin determination. Biochem.1938;297:81.

16. Grant GH. Amino Acids and Proteins. In: Tiez, N.W. editor. Fundamentals of Clinical Chemistry, $3^{\text {rd }}$ Edition. WB Saunders, Philadelphia; 1987:328-30.

17. Weatherburn MW. Urease-Berthelot Colorimetric Method for Invitro Determination of Urea. Anal. Chem. 1967;39:971.

18. Bartels H, Bohmer M. Quantitative Determination of Creatinine. Clin. Chem. Acta. 1972;18(1):216.

19. Coppin JP, Xu Y, Chen H, Pan MH, Ho CT, Juliani $\mathrm{R}$, et al. Determination of flavonoids by LC/MS and anti-inflammatory activity in Moringa oleifera. J. Funct. Foods. 2013;5:1892-99.

20. Ndukaku OY, Emmanuel EU, Mercy EA, Caroline NO. Evaluation of the Serum Liver Enzymes Markers, Lipid Profile and Kidney Function Parameters in Typhoid Patients IJTDH. 2015;8(2):79-89.

21. Adeosun OG, Oduola T, Akanji BO, Sunday AM, Udoh SJ, Bello IS. Biochemical alteration in Nigerian children with acute Falciparum malaria. Afr. J. Biotechnol. 2007;67:881-5.

22. Etim OE, Ekaidem IS, Akpan EJ, Usoh IF, Akpan HD. Effects of quinine treatment on some indices of protein metabolism in plasmodium falciparum infected human subjects. Acta. Pharm. Sci. 2009;51:21-6.

23. Abro AH, Abdou AM, Gangwan JL. Hematological and Biochemical changes in Typhoid fever. Pak. J. Med. Sci. 2009;25:166-17.

Cite this article as: Nasiru S, Bulama I, Bagudo Ibrahim A, Zayyanu A. Effect of Moringa oleifera aqueous leaf extract on hepato-renal changes of albino rats induced with Salmonella typhimurium. Int J Basic Clin Pharmacol 2017;6:734-8. 